\title{
PERSEPSI MAHASISWA PENDIDIKAN AKUNTANSI TENTANG KURIKULUM AKUNTANSI SYARIAH
}

\author{
Anggita Langgeng Wijaya \\ Pendidikan Akuntansi IKIP PGRI Madiun \\ Jl. Setia Budi No.85 Madiun \\ Email: gonggeng14@gmail.com
}

\begin{abstract}
This research examine the perception of accounting education student about curriculum of islamic accounting. Population of this research is all of student from accounting education department at IKIP PGRI Madiun. This research is type of descriptive research in which data taken by quaestionaire. In this study, sample consist ninthy two students from three accounting theory class. The result of this research show that perception of accounting education student suggest that islamic accounting curriculum because it is importance to add new knowlande and support future student carier.
\end{abstract}

Key word: accounting education, curriculum, islamic accounting, perception.

\begin{abstract}
ABSTRAKSI
Penelitian ini bertujuan untuk mengetahui persepsi mahasiswa program studi pendidikan akuntansi tentang kurikulum akuntansi syariah. Populasi dalam penelitian ini adalah seluruh mahasiswa program studi pendidikan akuntansi IKIP PGRI Madiun. Penelitian ini merupakan penelitian deskriptif dengan data yang diambil dengan kuesioner. Sampel dalam penelitian ini terdiri dari 92 mahasiswa kelas teori akuntansi. Hasil penelitian ini menunjukkan bahwa mahasiswa menilai kurikulum akuntansi syariah penting untuk diberikan kepada mahasiwa program studi pendidikan akuntasi karena dinilai penting bagi mahasiswa sebagai tambahan ilmu pengetahuan baru dan mendukung karir mahasiwa di masa depan.
\end{abstract}

Kata kunci: pendidikan akuntansi, kurikulum, akuntansi syariah, persepsi.

\section{PENDAHULUAN}

Aryanto Dina dan Mukhtaruddin (2004) menyatakan bahwa akuntansi terus berkembang sejalan dengan perkembangan peradaban manusia. Satu per satu ilmu akuntansi kontemporer mulai bermunculan. Akuntansi syariah adalah salah satu diantaranya. Akuntansi Syariah pada dasarnya adalah embrio dari akuntansi dalam islam yang menyajikan metoda pencatatan dan perhitungan akuntansi yang 
sedikit berbada dengan akuntansi konvensional. Perkembangan akuntansi syariah pun telah sampai pada tahap aplikasi dan tidak lagi pada tahap ilmu pengetahuan. Hal ini terlihat dengan banyak munculnya lembanga keuangan dan non keuangan dengan basis syariah.

Rifqi Muhammad dan Peni Nugraheni (2011) menyebutkan bahwa industri keuangan syariah telah menjadi sebuah potensi yang besar dalam bisnis global. Di Indonesia, perembangan lembaga syariah dimulai dengan berdirinya Bank Muamalat Indonesia tahun 1992. Sementara lembaga keuangan non bank seperti Asuransi Syariah, Reksadana Syariah, Pegadaian Syariah dan lembaga keuangan nirlaba seperti Lembaga Amil Zakat dan Badan Pengelola Wakaf juga mengalami perkembangan yang cukup signifikan.

Mokhamad Anwar (2010) menjelaskan bahwa di Indonesia pada tahun 2010, telah ada lebih dari lima belas bank yang memiliki sistem operasi ganda, yaitu menjalakan aktivitas sebagai bank konvensional dan juga menjalankan sistem perbankan syariah. Bank Indonesia sebagai bank sentral telah memberikan banyak dukungan dalam perkembangan bank syariah. Bank Indonesia memiliki direktorat khusus bidang syariah yang menangani masalah-masalah bank syariah, melakukan pelatihan, seminar dan workshop dan berbagai konferensi yang ditujukan untuk berbagi pengetahuan untuk mengembangankan sistem perbankan syariah.

Perkembangan sistem ekonomi syariah juga merambah berbagai sektor lain diluar bank. Perum pegadaian juga memiliki pegadaian syariah selain itu pada tingkat daerah seperti di Kabupaten dan Kota Madiun banyak berkembang lembangan keuangan syariah seperti BPR Syariah dan koperasi simpan pinjam syariah. Hal ini memunculkan pemikiran bahwa perkembangan ekonomi syariah yang pesat membuntuhkan dukungan sumber daya manusia yang paham dan kompeten dalam akuntansi syariah. Hal yang perlu dipikirkan adalah kesiapan lembaga pendidikan terutama perguruan tinggi dalam menghadapi pesatnya perkembangan ekonomi syariah. Perguruan tinggi diharapkan mampu merespon permintaan pasar yang tinggi akan sumber daya manusia yang berkualitas dalam bidang ekonomi syariah.

Rifqi Muhammad dan Peni Nugraheni (2011) menyetakan bahwa perkembangan yang pesat dalam industri dengan basis syariah ternyata belum diikuti dengan perkembangan yang signifikan dalam bidang pendidikan ekonomi dan keuangan syariah. Perkembangan pendidikan tinggi Ekonomi Islam justru diinisiasi oleh beberapa perguruan tinggi (PT) swasta seperti misalnya Universitas Islam Indonesia (UII), Universitas Muhammadiyah Yogyakarta (UMY), Universitas HAMKA, STEI SEBI, STEI TAZKIA dan Universitas Trisakti. Sedangkan universitas-universitas negeri baru merespon sekitar 3 tahun terakhir seperti Universitas Airlangga, Universitas Indonesia, Institut Pertanian Bogor dan Universitas Islam Negeri (UIN).

Aryanto Dina dan Mukhtaruddin (2004) menyebutkan bahwa perkembangan yang pesat dalam akuntansi syariah akan membeirkan dampak yang cukup besar terhadap dunia pendidikan terutama pendidikan akuntansi. Fakta yang ada membuat pihak akademisi melihat kembali kurikuum yang telah disusun sebelumnya. Apakah kurikulum pendidikan yang ada saat ini telah 
memberikan kontribusi bagi lulusannya sehingga mampu bersaing dalam dunia kerja. Dengan semakin banyaknya lembanga keuangan dan non keuaangan yang berbasis syariah maka sudah seharusnya lembaga pendidikan pada tingkat perguruan tinggi khususnya juruan ekonomi atau akuntansi melakukan desain ulang kurikulum nya dengan memberikan mata kuliah akuntansi syariah.

Pertanyaan yang mencul adalah bagaimana dengan lembaga dengan basis keguruan dan ilmu pendidikan? Sebagai salah satu Lembaga Pendidikan Tenaga Keguruan (LPTK), IKIP PGRI Madiun memiliki tujuan utama mencetak tenaga keguruan yang cerdas dan bermatabat. Pembelajaran tentang akuntansi syariah diperlukan agar memberikan tambahan pengetahuan kepada mahasiswa tentang akuntansi kekinian. Hal ini diperlukan karena pada kenyataannya tidak semua lulusan pendidikan akuntansi IKIP PGRI Madiun bekerja sebagai tenaga pendidik. Ada beberapa lulusan yang bekerja di perusahaan. Dengan mempertimbangkan besarnya permintaan pasar akan ekonomi syariah maka melalui penelitian ini peneliti akan mencoba memberikan deskripsi tentang persepsi mahasiswa pendidikan akuntansi IKIP PGRI Madiun tentang kurikulum akuntansi syariah.Tujuannya adalah mengetahuai persepsi mahasiswa pendidikan akuntansi IKIP PGRI Madiun tentang akuntansi syariah secara keilmuan dan kebermanfaatannya dalam mendukung karir mahasiswa di dunia kerja.

\section{TELAAH LITERATUR}

Mumahad (2007) menjelaskan bahwa akuntansi syariah dapat dikategorikan sebagai pengetahuan ilmu dalam bidang akuntansi yang memiliki karakteristik, kebenaran dan nilai-nilai Islami, yang digali menggunakan epistimologi Islam. Kerangka konseptual akuntansi syariah dikembangkan menggunakan prinsip dasar paradigma syariah (the fundamental of the syaria'ah paradigm). Akuntansi syariah dapat dipandang sebagai kontruksi sosial masyarakat Islam guna menerapkan ekonomi Islam dalam kegiatan ekonomi. Akuntansi syariah merupakan sub-sistem dari sistem ekonomi dan keuangan Islam, digunakan sebagai instrument pendukung penerapan nilai-nilai Islami dalam ranah akuntansi, fungsi utamanya adalah sebagai alat manajemen menyediakan informasi kepada pihak internal dan eksternal organisasi.

Etik Emilia Sula (2010) menyatakan Undang-undang No. 10 Tahun 1998 tentang Penyempurnaan Undang-undang No.7 Tahun 1992 tentang Perbankan merupakan langkah yang baik dalam perkembangan perbankan, terutama bagi perbankan syariah. Disahkannya Undang-undang No. 10 Tahun 1998 memberikan peluang bagi perbankan terutama bank-bank konvensional untuk melakukan dual banking system terhadap sistem operasionalnya dengan membuka unit usaha syariah (UUS) bahkan mendirikan sendiri badan usaha syariah (BUS). Tidak hanya itu, dengan dikeluarkannya undang-undang ini telah membuka kesempatan lebih luas bagi bank syariah, baik yang UUS maupun BUS untuk berkembang, bahkan dalam hal pengembangan inovasi produk-produknya. Maka tidak heran jika perkembangan bank syariah keberadaannya selalu menunjukkan trend yang meningkat. Dari jumlah kuantitas, kalau mau dibandingkan dengan keberadaannya pertama kali di tahun 1992 dengan bank Muamalat sebagai pencetus pertama lahirnya bank syariah, hingga sekarang di tahun 2010 terjadi peningkatan yang cukup bagus dari segi kuantitas. 
Dwi Andik Saputro (2010) enyatakan perkembangan kajian akuntansi syariah berbanding lurus dengan pesatnya kemajuan industri perbankan syariah, meskipun secara teoritis peruntukannya tidak sebatas bagi industri perbankan syariah, tetapi untuk kegiatan muamalah yang berdasar syariat secara umum. Adanya perbedaan landasan konsep dan praktik perbankan syariah memungkinkan adanya perbedaan perlakuan akuntansi terhadapnya. Hal ini mengharuskan para akedemisi untuk berpikir ulang apakah lulusan perguruan tinggi saat ini terutama di bidang akuntansi telah memiliki kemampuan yang memadai dalam bidang akuntansi syariah mengingat besarnya permintaan pasar akan renaga kerja yang berkualitas bidang akuntansi keuangan syariah. Aryanto Dina dan Mukhtaruddin (2004) menyebutkan bahwa perkembangan yang pesat dalam bidang keuangan syariah hendaknya dapat direspon dengan baik oleh perguruan tinggi dengan memberikan bekal kepada mahasiswanya pengetahuan tentang akuntansi dan keuangan syariah.

Menurut Muhamad (2007), dalam upaya untuk mendorong tersusunnya norma-norma keuangan syariah yang seragam dan pengembangan produk yang selaras antara aspek syariah dan kehati-hatian, telah dilakukan pembahasan bersama didalam Komite Akuntansi Syariah dimana Bank Indonesia sebagai salah satu anggotanya bersama Ikatan Akuntan Indonesia dan pihak lainnya. Komite Akuntansi Syariah bersama dengan Dewan Standar Akuntansi Keuangan - Ikatan Akuntan Indonesia telah mengeluarkan Pernyataan Standar Akuntansi Keuangan untuk transaksi kegiatan usaha dengan mempergunakan akuntasi berdasarkan kaidah syariah. Berikut ini daftar Standar Akutansi Keuangan yang juga akan berlaku bagi perbankansyariah : (1) Kerangka Dasar Penyusunan dan Penyajian Laporan Keuangan Syariah, (2) PSAK 101 (Revisi 2006) tentang Penyajian Laporan Keuangan Syariah, (3) PSAK 102 (Revisi 2006) tentang Akuntansi Murabahah, (4) PSAK 103 (Revisi 2006) tentang Akuntansi Salam, (5) PSAK 104 (Revisi 2006) tentang Akuntansi Istishna', (6) PSAK 105 (Revisi 2006) tentang Akuntansi Mudharabah, (7) PSAK 106 (Revisi 2006) tentang Akuntansi Musyarakah.

Rifqi Muhammad dan Peni Nugraheni (2011) Indonesia merupakan salah satu negara yang cukup konsisten dalam pengembangan industri keuangan Syariah. Hal ini tampak dari upaya pemerintah dengan menerbitkan UU Nomor 21 Tahun 2008 tentang Perbankan Syariah dan UU Nomor 19 Tahun 2008 tentang Surat Berharga Syariah Negara (SBSN). Bahkan saat ini Indonesia telah menjadi negara yang memiliki Lembaga Keuangan Syariah (LKS) terbanyak di dunia. Namun demikian, masalah utama yang saat ini dihadapi oleh industri keuangan Syariah Indonesia adalah kurangnya jumlah sumber daya yang memiliki kompetensi dan kualifikasi dalam bidang Ekonomi Islam dan Keuangan Syariah. Sektor Perbankan Syariah saat ini baru bisa menyerap tenaga kerja sebesar 15.000 orang. Sedangkan dalam empat hingga lima tahun mendatang dibutuhkan setidaknya 40.000 - 42.000 sumber daya manusia belum termasuk lembaga keuangan non bank dan lembaga keuangan mikro Syariah.

Kusuma (2006) menyatakan bahwa salah satu problematika utama yang dihadapi oleh industri keuangan Syariah adalah minimnya kuantitas dan kualitas SDM yang menguasasi ilmu ekonomi dan keuangan dengan basis ilmu Syariah 
yang cukup kuat. Pembentukan SDM bagi industri keuangan Syariah sebenarnya tidak dapat dicapai dalam waktu singkat dan diperlukan perencanaan konsep kurikulum yang memadai serta fokus pada bidang profesi tertentu.

IKIP PGRI madiun mencoba menangkap perkembangan lembaga keuangan syariah yang pesat dengan melakukan re-design kurikulum dan memasukan akuntansi syariah sebagai mata kuliah tersendiri dengan bobot 2 SKS. Meskipun tujuan utama IKIP PGRI Madiun adalah menghasilkan tenaga professional di bidang kependidikan, namun tidak dapat dipungkiri bahwa tidak sedikt pula lulusan yang bekerja di sektor non kependidikan. Hal ini membuat pendidikan akuntansi IKIP PGRI Madiun mencoba memberikan bekal tambahan kepada mahasiswa dengan memasukan akuntansi syariah ke dalam kurikulum. Paper ini akan mencoba memberikan gambaran tentang pendapat mahasiswa pendidikan akuntansi IKIP PGRI Madiun tentang kurikulum akuntansi syariah terutama berkitan dengan nilai mata kuliah ini secara keilmuan dan dalam menunjang karir lulusan.

\section{METODA PENELITIAN}

\section{Jenis penelitian}

Penelitian ini termasuk dalam jenis penelitian deksriptif karena hanya akan memberikan gambaran tentang persepsi mahasiswa pendidikan akuntansi IKIP PGRI Madiun tentang kurikulum akuntansi syariah.

\section{Data, Populasi dan Sampel}

Data dalam penelitian ini diambil dengan menggunakan kuesioner yang dikembangan berdasar penelitian Aryanto Dina dan Mukhtaruddin (2004). Kuesioner terdiri dari 11 pernyataan yang menyetakan persepsi dari mahasiswa pendidikan akuntansi tentang kurikulum akuntansi syariah. Kuesioer menggunakan skala likert 5 dengan pilihan jawaban 1) sangat tidak setuju, 2) tidak setuju, 3) netral, 4) setuju, 5) sangat setuju.

Populasi dalam penelitian ini adalah mahasiswa pendidikan akuntansi IKIP PGRI Madiun. Sampel dalam penelitian ini adalah mahasiswa semester VI pendidikan akuntansi pada tahun ajaran 2010/2011. Tujuannya adalah mahasiswa semester VI sedang menempuh mata kuliah teori akuntansi sehingga diharapkan lebih paham akan konsep-konsep yang ada dalam akuntansi. Jumlah responden sebanyak 92 mahasiswa yang terdiri dari tiga kelas pararel yaitu kelas VIA, kelas VIB dan kelas VIC.

\section{Teknik Analisis Data}

\section{Uji Validitas}

Uji validitas dilakukan untuk menilai seberapa baik suatu instrument ataupun proses pengukuran terhadap konsep yang diharapkan untuk mengetahui apakah yang ditanyakan dalam kuesioner sudah sesuai dengan konsepnya (Imam Ghozali, 2005). Uji validitas dalam penelitian ini menggunakan pendekatan Pearson Correlation. Sebuah data dikatakan valid jika skor kuesioner berkorelasi signifikan dengan skor total kuesioner. (Imam Ghozali, 2005)

\section{Uji Reliabilitas}

Uji reliabilitas merupakan uji yang dilakukan untuk mengukur apakah kuesioner benar-benar merupakan indikator yang mengukur suatu variabel. Suatu kuesioner 
dikatakan reliabel apabila jawaban seseorang konsisten dari waktu ke waktu. Reliabilitas dalam penelitian ini diuji dengan metode Cronbach's Alpha. Dikatakan reliabel jika nilai Cronbach's Alpha diatas 0.6 (Imam Ghozali, 2005).

\section{Uji Statistik Deskriptif}

Statistik deskriptif bertujuan memberikan gambaran tentang pendapat mahasiswa pendidikan akuntansi IKIP PGRI Madiun tentang masuknya akuntansi syariah dalam kurikulum pendidikan akuntansi IKIP PGRI Madiun.

\section{ANALISIS DAN PEMBAHASAN}

Penelitian ini bertujuan mengetahui persepsi mahasiswa pendidikan akuntansi IKIP PGRI madiun tentang kurikulum akuntansi syariah. Sebelum dilakukan analisis lenih lanjut, dilakukan analisis pendahuluan berupa uji validitas dan uji reliabilitas data. Hasil uji validitas dalam penelitian ini tersaji pada tabel berikut ini.

\section{Sisipkan tabel 1 disini}

Berdasar tabel di atas dikutehui bahwa semua item pertanyaan memiliki korelasi yang signifikan dengan skor total pertanyaan. Tidak ada data yang harus dikeluarkan dari analisis, semua item pertanyaan valid dan layak pada tahap analisis selanjutnya.

Hasil uji reliabilitas menunjukkan nilai Cronbach's Alpha sebesar 0.795, nilai tersebut lebih besar dari 0.6 sehingga dapat disimpulkan bahwa data dalam penelitian ini telah memenuhi syarat reliabilitas data.

Setelah data lolos uji validitas dan reliabilitas data maka langkah selanjutnya adalah melakukan analisis deskriptif terhadap data penelitian. Berikut ini adalah rekaptulasi jawaban responden untuk masing-masing item pertanyaan penelitian.

\section{Sisipkan tabel 2 disini}

Berdasarkan jawaban responden dapat diambil analisis sebagai berikut.

1. Sebanyak 49 responden atau $53.3 \%$ menyatakan sangat setuju bahwa mahasiswa pendidikan akuntansi harus selalu mengikuti perkambangan akuntansi, 38 responden $(41.3 \%)$ menyatakan setuju, 4 responden $(4.3 \%)$ menyatakan netral dan 1 responden $(1.1 \%)$ menyatakan tidak setuju. Hasil ini memberikan implikasi bahwa meskipun berasal dari kampus dengan latar belakang keguruan dan ilmu pendidikan, mahasiswa pendidikan akuntansi menilai bahwa perkembangan akuntansi yang kekinian harus tetap diikuti.

2. Sebanyak 48 responden atau $52.2 \%$ menyatakan tidak setuju bahwa mahasiswa pendidikan akuntansi yang tidak mempelajari akuntansi syariah akan tertinggal dalam hal perkembangan akuntansi, 31 responden $(33.7 \%)$ menyatakan setuju, 7 responden $(7.6 \%)$ menyatakan sangat setuju, 4 responden $(4.3 \%)$ 
menyatakan netral dan 2 responden $(2.2 \%)$ menyatakan tidak setuju. Point ini menunjukan konsentrasi jawaban pada jawaban setuju dan tidak setuju dengan mayoritas justru tidak setuju. Hasil penelitian ini tidak konsisten dengan hasil penelitian Aryanto Dina dan Mukhtaruddin (2004) yang menunjukkan ratarata responden memberikan respon setuju. Penulis menduga terdapat dua kemungkinan yang menyebabkan perbedaan, yang pertama mahasiswa yang menjadi responden tidak begitu paham akan perkembangan akuntansi syariah saat ini sehingga tidak terlalu mengatahui potensi akan besarnya sumber daya manusia yang paham di bidang akunatnsi syariah. Kemungkinan kedua, responden adalah mahasiswa dengan latar belakang keguruan dan ilmu pendidikan sehingga tujuan utamanya adalah menjadi guru. Akuntansi syariah dianggap penting namun seberapa penting akuntansi syariah sebagai bekal karir belum terlalu dipahami.

3. Sebanyak 55 responden atau $59.8 \%$ menyatakan setuju bahwa mahasiswa akuntansi Syariah menjadi sangat penting untuk dipelajari mengingat sudah banyak dunia usaha yang menerapkan akuntansi syariah dalam sistem akuntansinya, 19 responden $(27.7 \%)$ menyatakan sangat setuju, 9 responden $(9.8 \%)$ menyatakan tidak setuju, 8 responden $(8.7 \%)$ menyatakan netral dan 1 responden $(1.1 \%)$ menyatakan sangat tidak setuju. Hasil ini menunjukkan adanya ketertarikan mahasiswa pendidikan akuntansi terhadap akuntansi syariah sehinga menilai masuknya akuntansi syariah dalam kurikulum menjadi hal yang penting mengingat telah banyaknya badan usaha yang menggunaka sistem syariah.

4. Sebanyak 55 responden atau 59.8\% menyatakan setuju bahwa pengetahuan akuntansi syariah yang diperoleh di bangku kuliah dirasa belum mencukupi, 21 responden $(22.8 \%)$ menyatakan sangat setuju, 6 responden $(6.5 \%)$ menyatakan netral dan 10 responden (10.9\%) menyatakan tidak setuju. Tidak dipungkiri bahwa di IKIP PGRI Madiun sebelumnya tidak ada dosen yang secara khusus memberikan pengetahuan tentang akuntansi syariah kepada mahasiswa, hanya bersifat sepintas saja. Pada mata kuliah tertentu seperti dasar-dasar akuntansi, seminar akuntansi maupun teori akuntansi tidak ada dosen yang secara khusus pada satu pertemuan membahas tentang akuntansi syariah sehingga dapat dikatakan sebenarnya mahasiswa yang menjadi responden dalam ini memang belum mengetahui secara mendalam tentaang akuntansi syariah.

5. Sebanyak 48 responden atau 52.2\% menyatakan setuju bahwa akuntansi syariah memiliki proporsi yang sama dengan akuntansi konvensional untuk dipelajari, 28 responden $(30.4 \%)$ menyatakan tidak setuju, 9 responden $(9.8 \%)$ menyatakan netral, 6 responden $(6.5 \%)$ menyatakan sangat setuju dan 1 responden $(1.1 \%)$ menyatakan sangat tidak setuju. Hal ini menunjukkan adanya kesadaran mahasiswa pendidikan akuntansi bahwa akuntansi syariah itu penting dipelajari sebagaimana akuntansi konvensional yang diajarkan saat ini. 
6. Sebanyak 64 responden atau $69.6 \%$ menyatakan setuju bahwa Mata kuliah teori akuntansi belum cukup memberikan gambaran tentang akuntansi syariah, 14 responden $(15.2 \%)$ menyatakan sangat setuju, 8 responden $(8.7 \%)$ menyatakan tidak setuju dan 6 responden $(6.5 \%)$ menyatakan netral. Pada kenyataannya dosen teori akuntansi di IKIP PGRI Madiun memang hanya mengajar teori akuntansi konvensional dan tidak membahas tantang akuntansi syariah secara mendalam.

7. Sebanyak 50 responden atau $54.3 \%$ menyatakan setuju bahwa akuntansi syariah memiliki prospek yang cerah di masa yang akan datang karena nantinya akan benyak dunia usaha yang menggunakan akuntansi syariah, 16 responden (17.4\%) menyatakan sangat setuju, 15 responden $(16.3 \%)$ menyatakan tidak setuju dan 11 responden (12\%) menyatakan netral. Hasil ini menunjukkan bahwa mahasiswa telah cukup menyadari bahwa banyak lembaga profit dan non profit di tingkat nasional maupun dalam lingkup wilayah Kabupaten/Kota Madiun yang menggunakan akuntansi syariah, sehingga menilai memperlajari akuntansi syariah memiliki prospek yang cerah sebagai bekal dalam meniti karir di masa depan.

8. Sebanyak 54 responden atau $58.7 \%$ menyatakan setuju bahwa mahasiswa pendidikan akuntansi harus mengikuti mata kuliah akuntansi syariah agar tidak ketinggalan dengan kampus lain, 26 responden (28.3\%) menyatakan sangat setuju, 7 responden $(7.6 \%)$ menyatakan tidak setuju dan 5 responden $(5.4 \%)$ menyatakan netral. Hasil penelitian ini menunjukkan bahwa mahasiswa pendidikan akuntansi IKIP PGRI madiun menyatakan setuju apabila mata kuliah akuntansi syariah masuk ke dalam kurikulum pendidikan akuntansi agar tetap menjaga kualitas lulusan supya tidak tertinggal jika dibandingkan dengan perguruan tinggi lainnya.

9. Sebanyak 51 responden atau $55.4 \%$ menyatakan setuju bahwa mahasiswa lulusan S-1 pendidikan akuntansi harus memiliki pengetahuan tentang akuntansi syariah, 23 responden (25\%) menyatakan sangat setuju, 10 responden $(10.9 \%)$ menyatakan tidak setuju dan 8 responden $(8.7 \%)$ menyatakan netral. Hasil ini menunjukkan bahwa akuntansi syariah dibutuhkan oleh mahasiswa ketika lulus dan terjun ke dunia kerja.

10. Sebanyak 44 responden atau $47.8 \%$ menyatakan setuju bahwa mata kuliah akuntansi syariah menunjang karir mahasiswa, 22 responden $(23.9 \%)$ menyatakan tidak setuju, 17 responden (18.5\%) menyatakan netral, dan 8 responden $(8.7 \%)$ menyatakan sangat setuju dan 1 responden $(1.1 \%)$ menyatakan sangat tidak setuju. Dengan melihat pesatnya pekrmbangan bisnis dengan label syariah maka mahasiswa pendidikan akuntansi perlu dibekali dnegan pengetahun tentang akuntansi syariah. Pengetahuan akuntansi syariah akan dapat menunjang karir lulusan ketika terjun ke dunia kerja. 
11. Sebanyak 51 responden atau $55.4 \%$ menyatakan setuju bahwa mata kuliah akuntansi syariah layak masuk dalam kurikulum pendidikan akuntansi, 28 responden $(30.4 \%)$ menyatakan sangat setuju, 9 responden $(9.8 \%)$ menyatakan netral dan 4 responden $(4.3 \%)$ menyatakan tidak setuju. Hasil ini menunjukkan bahwa dengan mempertimbangkan aspek tambahan pengetahuan serta peluang pekerjaan yang cukup terbuka dibidang akuntansi syariah maka mahasiswa pendidikan akuntansi IKIP PGRI menyatakan setuju bahwa akuntansi syariah masuk kedalam kurikulum pendidikan akuntansi IKIP PGRI Madiun.

\section{KESIMPULAN}

Penelitian ini bertujuan mengetahui persepsi mahasiswa pendidikan akuntansi IKIP PGRI madiun tentang kurikulum akuntansi syariah. Hasil penelitian ini menunjukkan bahwa sebagian besar mahasiswa pendidikan akuntansi berpendapat bahwa akuntansi syariah penting untuk dipelajari, layak masuk dalam kurikulum pendidikan akuntansi IKIP PGRI, menambah pengetahuan mahasiswa dibidang akuntansi kekinian serta menunjang karir lulusan ketika terjun ke dunia kerja.

Implikasi hasil penelitian ini adalah prodi pendidikan akuntansi IKIP PGRI Madiun disarankan untuk memasukan akuntansi syariah dalam kurikulumnya. Apabila kurikulum akuntansi syariah diperuntukan bagi mahasiswa baru maka hendaknya mahasiswa lama (diluar semester I di tahun ajaran 20112012) hendaknya diberi pengetahuan tentang akuntansi syariah melalui mata kuliah yang lain seperti: teori akuntansi, seminar akuntansi atau akuntansi keuangan menengah.

Penelitian ini tidak lepas dari beberapa keterbatasan. Keterbatasan penelitian antara lain hanya dilakukan pada mahasiswa mata kuliah teori akuntansi studi pendidikan akuntansi IKIP PGRI Madiun sehingga hasil penelitian ini tidak dapat digunakan untuk melakukan generalisasi. Penelitian selanjutnya disarankan untuk memperluas sampel penelitian. 


\section{DAFTAR PUSTAKA}

Aryanto Dina dan Mukhtaruddin. 2004. "Persepsi Mahasiswa Akuntansi Terhadap Urgensi Syariah dan Relevansinya dalam Kurikulum Akuntansi”. Fordema Vol.4 No.1 Hal. 709-724

Dwi Andik Saputro. 2010. 'Koreksi Konsep Nilai Tambah Syari'ah: Menimbang Pemikiran Konsep Dasar Teoritis Laporan Keuangan Akuntansi Syari'ah Makalah disampaikan pada Simposium Nasional Akuntansi XII di Universitas Sriwijaya, Palembang.

Etik Emilia Sula. 2010. "Reformulasi Akad Pembiayaan Murabahah Dengan Sistem Musyarakah Sebagai Inovasi Produk Perbankan Syariah". Makalah disampaikan pada Simposium Nasional Akuntansi XII di Universitas Jendral Soedirman, Purwokerto.

Imam Ghozali. 2005. Analisis Multivariat dengan Program SPSS. Badan Penerbit Universitas Diponegoro: Semarang.

Kusuma, A. C. 2006. "Ekonomi Islam: aplikasi dan pengembangan keilmuan di perguruan tinggi Islam". Jurnal Hukum Islam, 5(3), Juli, 321-342.

Mokhamad Anwar. 2010. "Cost Components as Predictors for the Profitability of sharia Banks :(Study on PT. Bank Syariah Mandiri and PT. Bank Syariah Mega Indonesia)". (online), (http//www:ssrn.com, diakses 18 Juli 2011).

Mumahad. 2007. "Rekonstruksi Kerangka Dasar Konseptual Untuk Akuntansi dan Pelaporan Keuangan Syariah" (online), (http//:www.mercubuana.ac.id, diakses 8 Juni 2011).

Rifqi Muhammad dan Peni Nugraheni. 2011. "Model Pendidikan Berbasis Kompetensi Bagi SDI Perbankan Syariah Indonesia". Makalah disampaikan pada Seminar Nasional Kontribusi Dunia Pendidikan ekonomi, Manajemen dan akuntansi dalam penguatan perekonomian bangsa di Universitas Islam Indonesia, Yogyakarta. 


\section{Lampiran 1}

\section{Kuesioner Penelitian}

Petunjuk :

Berilah tanda silang (X) atau tanda lingkaran (O) pada jawaban Anda, skala yang digunakan adalah likert 5 poin. Pilihan jawaban:

STS= Sangat tidak setuju, TS=tidak setuju, $N=$ netral, $S=$ setuju, $S S=$ Sangat setuju .

\begin{tabular}{|c|c|c|c|c|c|c|}
\hline NO & PERNYATAAN & STS & TS & $\mathrm{N}$ & $\mathrm{S}$ & SS \\
\hline 1 & $\begin{array}{l}\text { Mahasiswa pendidikan akuntansi harus } \\
\text { selalu mengikuti perkembangan } \\
\text { akuntansi }\end{array}$ & 1 & 2 & 3 & 4 & 5 \\
\hline 2 & $\begin{array}{l}\text { Mahasiswa pendidikan akuntansi yang } \\
\text { tidak mempelajari akuntansi syariah } \\
\text { akan tertinggal dalam hal } \\
\text { perkembangan akuntansi }\end{array}$ & 1 & 2 & 3 & 4 & 5 \\
\hline 3 & $\begin{array}{l}\text { Akuntansi Syariah menjadi sangat } \\
\text { penting untuk dipelajari mengingat } \\
\text { sudah banyak dunia usaha yang } \\
\text { menerapkan akuntansi syariah dalam } \\
\text { sistem akuntansinya }\end{array}$ & 1 & 2 & 3 & 4 & 5 \\
\hline 4 & $\begin{array}{l}\text { Pengetahuan akuntansi syariah yang } \\
\text { diperoleh di bangku kuliah dirasa belum } \\
\text { mencukupi }\end{array}$ & 1 & 2 & 3 & 4 & 5 \\
\hline 5 & $\begin{array}{l}\text { Akuntansi syariah memiliki proporsi } \\
\text { yang sama dengan akuntansi } \\
\text { konvensional untuk dipelajari }\end{array}$ & 1 & 2 & 3 & 4 & 5 \\
\hline 6 & $\begin{array}{l}\text { Mata kuliah teori akuntansi belum } \\
\text { cukup memberikan gambaran tentang } \\
\text { akuntansi syariah }\end{array}$ & 1 & 2 & 3 & 4 & 5 \\
\hline 7 & $\begin{array}{l}\text { Akuntansi syariah memiliki prospek } \\
\text { yang cerah di masa yang akan dating } \\
\text { karena nantinya akan benyak dunia } \\
\text { usaha yang menggunakan akuntansi } \\
\text { syariah }\end{array}$ & 1 & 2 & 3 & 4 & 5 \\
\hline 8 & $\begin{array}{l}\text { Mahasiswa pendidikan akuntansi harus } \\
\text { mengikuti mata kuliah akuntansi } \\
\text { syariah agar tidak ketinggalan dengan } \\
\text { kampus lain }\end{array}$ & 1 & 2 & 3 & 4 & 5 \\
\hline 9 & $\begin{array}{l}\text { Mahasiswa lulusan S-1 pendidikan } \\
\text { akuntansi harus memiliki pengetahuan } \\
\text { tentang akuntansi syariah }\end{array}$ & 1 & 2 & 3 & 4 & 5 \\
\hline 10 & $\begin{array}{l}\text { Mata kuliah akuntansi syariah } \\
\text { menunjang karir saya }\end{array}$ & 1 & 2 & 3 & 4 & 5 \\
\hline 11 & $\begin{array}{l}\text { Mata kuliah akuntansi syariah layak } \\
\text { masuk dalam kurikulum pendidikan } \\
\text { akuntansi }\end{array}$ & 1 & 2 & 3 & 4 & 5 \\
\hline
\end{tabular}




\section{Lampiran 2}

\section{Tabel Penelitian}

Tabel 1

Hasil Uji Validitas

\begin{tabular}{lccc}
\hline Pertanyaan & Koefisien Korelasi & P-Value & Keterangan \\
\hline P1 & 0.253 & 0.015 & Valid \\
P2 & 0.288 & 0.000 & Valid \\
P3 & 0.691 & 0.000 & Valid \\
P4 & 0.421 & 0.000 & Valid \\
P5 & 0.564 & 0.000 & Valid \\
P6 & 0.423 & 0.000 & Valid \\
P7 & 0.612 & 0.000 & Valid \\
P8 & 0.630 & 0.000 & Valid \\
P9 & 0.691 & 0.000 & Valid \\
P10 & 0.710 & 0.000 & Valid \\
P11 & 0.667 & 0.000 & Valid \\
\hline
\end{tabular}

Sumber : Hasil Pengolahan Data 


\section{Lampiran 2}

Tabel Penelitian (Lanjutan)

Tabel 2

Deskripsi Jawaban Responden

\begin{tabular}{|c|c|c|c|c|c|c|}
\hline $\mathrm{NO}$ & PERNYATAAN & STS & TS & $\mathrm{N}$ & $S$ & SS \\
\hline 1 & $\begin{array}{l}\text { Mahasiswa pendidikan akuntansi harus } \\
\text { selalu mengikuti perkembangan } \\
\text { akuntansi }\end{array}$ & 0 & 1 & 4 & 38 & 49 \\
\hline 2 & $\begin{array}{l}\text { Mahasiswa pendidikan akuntansi yang } \\
\text { tidak mempelajari akuntansi syariah } \\
\text { akan tertinggal dalam hal } \\
\text { perkembangan akuntansi }\end{array}$ & 2 & 48 & 4 & 31 & 7 \\
\hline 3 & $\begin{array}{l}\text { Akuntansi Syariah menjadi sangat } \\
\text { penting untuk dipelajari mengingat } \\
\text { sudah banyak dunia usaha yang } \\
\text { menerapkan akuntansi syariah dalam } \\
\text { sistem akuntansinya }\end{array}$ & 1 & 9 & 8 & 55 & 19 \\
\hline 4 & $\begin{array}{l}\text { Pengetahuan akuntansi syariah yang } \\
\text { diperoleh di bangku kuliah dirasa belum } \\
\text { mencukupi }\end{array}$ & 0 & 10 & 6 & 55 & 21 \\
\hline 5 & $\begin{array}{l}\text { Akuntansi syariah memiliki proporsi } \\
\text { yang sama dengan akuntansi } \\
\text { konvensional untuk dipelajari }\end{array}$ & 1 & 28 & 9 & 48 & 6 \\
\hline 6 & $\begin{array}{l}\text { Mata kuliah teori akuntansi belum } \\
\text { cukup memberikan gambaran tentang } \\
\text { akuntansi syariah }\end{array}$ & 0 & 8 & 6 & 64 & 14 \\
\hline 7 & $\begin{array}{l}\text { Akuntansi syariah memiliki prospek } \\
\text { yang cerah di masa yang akan datang } \\
\text { karena nantinya akan benyak dunia } \\
\text { usaha yang menggunakan akuntansi } \\
\text { syariah }\end{array}$ & 0 & 15 & 11 & 50 & 16 \\
\hline 8 & $\begin{array}{l}\text { Mahasiswa pendidikan akuntansi harus } \\
\text { mengikuti mata kuliah akuntansi } \\
\text { syariah agar tidak ketinggalan dengan } \\
\text { kampus lain }\end{array}$ & 0 & 7 & 5 & 54 & 26 \\
\hline 9 & $\begin{array}{l}\text { Mahasiswa lulusan } \mathrm{S}-1 \text { pendidikan } \\
\text { akuntansi harus memiliki pengetahuan } \\
\text { tentang akuntansi syariah }\end{array}$ & 0 & 10 & 8 & 51 & 23 \\
\hline 10 & $\begin{array}{l}\text { Mata kuliah akuntansi syariah } \\
\text { menunjang karir saya }\end{array}$ & 1 & 22 & 17 & 44 & 8 \\
\hline 11 & $\begin{array}{l}\text { Mata kuliah akuntansi syariah layak } \\
\text { masuk dalam kurikulum pendidikan } \\
\text { akuntansi }\end{array}$ & 0 & 4 & 9 & 51 & 28 \\
\hline
\end{tabular}

Sumber : Hasil Pengolahan Data 


\section{Lampiran 3}

\section{Hasil Pengolahan Data}

\section{Descriptive Statistics}

\begin{tabular}{|l|r|r|r|r|r|}
\hline & $\mathrm{N}$ & \multicolumn{1}{|c|}{ Minimum } & Maximum & \multicolumn{1}{c|}{ Mean } & Std. Deviation \\
\hline P1 & 92 & 2.00 & 5.00 & 4.4674 & .63680 \\
P2 & 92 & 1.00 & 5.00 & 2.9239 & 1.12155 \\
P3 & 92 & 1.00 & 5.00 & 3.8913 & .88276 \\
P4 & 92 & 2.00 & 5.00 & 3.9457 & .85632 \\
P5 & 92 & 1.00 & 5.00 & 3.3261 & 1.01752 \\
P6 & 92 & 2.00 & 5.00 & 3.9130 & .75086 \\
P7 & 92 & 2.00 & 5.00 & 3.7283 & .93882 \\
P8 & 92 & 2.00 & 5.00 & 4.0761 & .80156 \\
P9 & 92 & 2.00 & 5.00 & 3.9457 & .88161 \\
P10 & 92 & 1.00 & 5.00 & 3.3913 & .98289 \\
P11 & 92 & 2.00 & 5.00 & 4.1196 & .75363 \\
Valid N (listwise) & 92 & & & & \\
\hline
\end{tabular}

\section{Reliability Statistics}

\begin{tabular}{|r|r|}
\hline $\begin{array}{c}\text { Cronbach's } \\
\text { Alpha }\end{array}$ & N of Items \\
\hline .795 & 11 \\
\hline
\end{tabular}

Item-Total Statistics

\begin{tabular}{|l|r|r|r|r|}
\hline & $\begin{array}{c}\text { Scale Mean if } \\
\text { Item Deleted }\end{array}$ & $\begin{array}{c}\text { Scale } \\
\text { Variance if } \\
\text { Item Deleted }\end{array}$ & $\begin{array}{c}\text { Corrected } \\
\text { Item-Total } \\
\text { Correlation }\end{array}$ & $\begin{array}{c}\text { Cronbach's } \\
\text { Alpha if Item } \\
\text { Deleted }\end{array}$ \\
\hline P1 & 37.2609 & 29.645 & .142 & .804 \\
P2 & 38.8043 & 24.950 & .431 & .784 \\
P3 & 37.8370 & 25.017 & .593 & .763 \\
P4 & 37.7826 & 27.754 & .282 & .796 \\
P5 & 38.4022 & 25.672 & .420 & .783 \\
P6 & 37.8152 & 28.064 & .303 & .793 \\
P7 & 38.0000 & 25.516 & .489 & .775 \\
P8 & 37.6522 & 26.054 & .530 & .771 \\
P9 & 37.7826 & 25.029 & .593 & .763 \\
P10 & 38.3370 & 24.226 & .604 & .761 \\
P11 & 37.6087 & 25.999 & .581 & .767 \\
\hline
\end{tabular}




\section{Lampiran 3}

Hasil Pengolahan Data (Lanjutan)

P1

\begin{tabular}{|ll|r|r|r|r|}
\hline & & & & \multicolumn{2}{c|}{$\begin{array}{c}\text { Cumulative } \\
\text { Percent }\end{array}$} \\
\hline Valid & Tidak Setuju & 1 & 1.1 & 1.1 & 1.1 \\
& Netral & 4 & 4.3 & 4.3 & 5.4 \\
& Setuju & 38 & 41.3 & 41.3 & 46.7 \\
& Sangat Setuju & 49 & 53.3 & 53.3 & 100.0 \\
& Total & 92 & 100.0 & 100.0 & \\
\hline
\end{tabular}

P2

\begin{tabular}{|ll|r|r|r|r|}
\hline & & & & Cumulative \\
& Frequency & Percent & Valid Percent & Percent \\
\hline Valid & Sangat Tidak Setuju & 2 & 2.2 & 2.2 & 2.2 \\
& Tidak Setuju & 48 & 52.2 & 52.2 & 54.3 \\
Netral & 4 & 4.3 & 4.3 & 58.7 \\
Setuju & 31 & 33.7 & 33.7 & 92.4 \\
Sangat Setuju & 7 & 7.6 & 7.6 & 100.0 \\
Total & 92 & 100.0 & 100.0 & \\
\hline
\end{tabular}

P3

\begin{tabular}{|ll|r|r|r|r|}
\hline & & & & \multicolumn{2}{c|}{$\begin{array}{c}\text { Cumulative } \\
\text { Percent }\end{array}$} \\
\hline Valid & Sangat Tidak Setuju & 1 & 1.1 & 1.1 & 1.1 \\
& Tidak Setuju & 9 & 9.8 & 9.8 & 10.9 \\
& Netral & 8 & 8.7 & 8.7 & 19.6 \\
Setuju & 55 & 59.8 & 59.8 & 79.3 \\
Sangat Setuju & 19 & 20.7 & 20.7 & 100.0 \\
Total & 92 & 100.0 & 100.0 & \\
\hline
\end{tabular}

P4

\begin{tabular}{|ll|r|r|r|r|}
\hline & & & & Cumulative \\
& & Frequency & Percent & Valid Percent & \multicolumn{1}{c|}{ Percent } \\
\hline Valid & Tidak Setuju & 10 & 10.9 & 10.9 & 10.9 \\
& Netral & 6 & 6.5 & 59.8 & 17.4 \\
& Setuju & 55 & 59.8 & 22.8 & 77.2 \\
& Sangat Setuju & 21 & 22.8 & 100.0 & 100.0 \\
& Total & 92 & 100.0 & \\
\hline
\end{tabular}




\section{Lampiran 3}

Hasil Pengolahan Data (Lanjutan)

P5

\begin{tabular}{|ll|r|r|r|r|}
\hline & & & & \multicolumn{2}{c|}{$\begin{array}{c}\text { Cumulative } \\
\text { Percent }\end{array}$} \\
\hline Valid & Sangat Tidak Setuju & 1 & 1.1 & 1.1 & 1.1 \\
& Tidak Setuju & 28 & 30.4 & 30.4 & 31.5 \\
Netral & 9 & 9.8 & 9.8 & 41.3 \\
Setuju & 48 & 52.2 & 52.2 & 93.5 \\
Sangat Setuju & 6 & 6.5 & 6.5 & 100.0 \\
Total & 92 & 100.0 & 100.0 & \\
\hline
\end{tabular}

P6

\begin{tabular}{|ll|r|r|r|r|}
\hline & & & & \multicolumn{2}{c|}{$\begin{array}{c}\text { Cumulative } \\
\text { Percent }\end{array}$} \\
\hline Valid & Tidak Setuju & 8 & 8.7 & 8.7 & 8.7 \\
& Netral & 6 & 6.5 & 6.5 & 15.2 \\
& Setuju & 64 & 69.6 & 69.6 & 84.8 \\
& Sangat Setuju & 14 & 15.2 & 15.2 & 100.0 \\
Total & 92 & 100.0 & 100.0 & \\
\hline
\end{tabular}

P7

\begin{tabular}{|c|c|c|c|c|c|}
\hline & & Frequency & Percent & Valid Percent & $\begin{array}{l}\text { Cumulative } \\
\text { Percent }\end{array}$ \\
\hline \multirow[t]{5}{*}{ Valid } & Tidak Setuju & 15 & 16.3 & 16.3 & 16.3 \\
\hline & Netral & 11 & 12.0 & 12.0 & 28.3 \\
\hline & Setuju & 50 & 54.3 & 54.3 & 82.6 \\
\hline & Sangat Setuju & 16 & 17.4 & 17.4 & 100.0 \\
\hline & Total & 92 & 100.0 & 100.0 & \\
\hline
\end{tabular}

P8

\begin{tabular}{|ll|r|r|r|r|}
\hline & & & & \multicolumn{2}{c|}{$\begin{array}{c}\text { Cumulative } \\
\text { Percent }\end{array}$} \\
\hline Valid & Tidak Setuju & 7 & 7.6 & 7.6 & 7.6 \\
& Netral & 5 & 5.4 & 5.4 & 13.0 \\
& Setuju & 54 & 58.7 & 58.7 & 71.7 \\
& Sangat Setuju & 26 & 28.3 & 28.3 & 100.0 \\
& Total & 92 & 100.0 & 100.0 & \\
\hline
\end{tabular}




\section{Lampiran 3}

Hasil Pengolahan Data (Lanjutan)

P9

\begin{tabular}{|ll|r|r|r|r|}
\hline & & & & \multicolumn{2}{c|}{$\begin{array}{c}\text { Cumulative } \\
\text { Percent }\end{array}$} \\
\hline Valid & Tidak Setuju & 10 & 10.9 & 10.9 & 10.9 \\
& Netral & 8 & 8.7 & 8.7 & 19.6 \\
& Setuju & 51 & 55.4 & 55.4 & 75.0 \\
& Sangat Setuju & 23 & 25.0 & 25.0 & 100.0 \\
& Total & 100.0 & 100.0 & \\
\hline
\end{tabular}

P10

\begin{tabular}{|ll|r|r|r|r|}
\hline & & & & \multicolumn{2}{c|}{$\begin{array}{c}\text { Cumulative } \\
\text { Percent }\end{array}$} \\
\hline Valid & Sangat Tidak Setuju & 1 & 1.1 & 1.1 & 1.1 \\
& Tidak Setuju & 22 & 23.9 & 23.9 & 25.0 \\
& Netral & 17 & 18.5 & 18.5 & 43.5 \\
Setuju & 44 & 47.8 & 47.8 & 91.3 \\
Sangat Setuju & 8 & 8.7 & 8.7 & 100.0 \\
Total & 92 & 100.0 & 100.0 & \\
\hline
\end{tabular}

P11

\begin{tabular}{|ll|r|r|r|r|}
\hline & & & & \multicolumn{2}{c|}{$\begin{array}{c}\text { Cumulative } \\
\text { Percent }\end{array}$} \\
\hline Valid & Tidak Setuju & Frequency & Percent & Valid Percent & 4.3 \\
& Netral & 4 & 4.3 & 4.3 & 14.1 \\
& Setuju & 9 & 9.8 & 9.8 & 69.6 \\
& Sangat Setuju & 28 & 55.4 & 55.4 & 100.0 \\
& Total & 30.4 & 30.4 & \\
\hline
\end{tabular}

